\title{
Pengaruh Penerapan Jaminan Kesehatan Nasional Terhadap Profil Obat Pasien Hipertensi di Puskesmas Kecamatan Pulogadung
}

\author{
Effects of National Health Insurance Implementation on Drug Profile of \\ Hypertension Patients in Primary Health Center of Pulogadung District
}

\author{
Yudha Sukowati $^{*}$, Dian Ratih Laksmitawati ${ }^{2}$, Yusi Anggriani ${ }^{2}$, Mita Restiana ${ }^{2}$ \\ ${ }^{1}$ Akademi Farmasi IKIFA \\ 2 Universitas Pancasila \\ Corresponding author: Yudha Sukowati: Email: yudhasukowati@gmail.com \\ Submitted: 02-04-2020 Revised: 05-10-2020 Accepted: 13-10-2020
}

\begin{abstract}
ABSTRAK
Jaminan Kesehatan Nasional (JKN) telah resmi dilaksanakan oleh Badan Penyelenggara Jaminan Sosial (BPJS) pada Bulan Januari 2014. Perubahan yang mendasar adalah masalah pembiayaan. Sebelum JKN menggunakan metode Free For Service (FFS), sesudah JKN menggunakan metode Indonesian Case Base Groups (INA-CBGs). Salah satu penyakit kronis yang membutuhkan pelayanan komprehensif dan terjadinya peningkatan jumlah pasien salah satunya adalah Hipertensi. Tujuan penelitian ini adalah untuk melihat pengaruh penerapan metode Indonesian Case Base Groups (INA-CBGS) pada program JKN terhadap profil pemenuhan obat pada pasien kronis hipertensi. Penelitian ini menggunakan desain longitudinal time series dengan alur penelitian data dilakukan secara retrospektif sebelum dan sesuah JKN dengan kriteria inklusi adalah pasien ASKES hipertensi yang merupakan pasien rutin dan melakukan rawat jalan di Puskesmas Kecamatan Pulogadung selama periode Januari 2013 - Desember 2015. Berdasarkan kriteria tersebut didapatkan sampel sebanyak 82 pasien. Data diambil berasal dari rekam medis, Laporan Permakaian dan Lembar Permintaan Obat (LPLPO), kartu stok, buku permintaan dan penerimaan obat, serta resep pasien hipertensi tahun 2013, 2014 dan 2015. Data penelitian ini dianalisis menggunakan uji asosiatif hubungan kausal (sebab akibat) untuk melihat seberapa besar pengaruh penerapan untuk metode Indonesian Case Base Groups (INA-CBGs) pada program JKN terhadap profil pemenuhan obat pada pasien kronis hipertensi dibandingkan dengan metode Free For Service (FFS). Hasil penelitian ini menunjukkan bahwa pada pasien hipertensi pada profil pengobatan menunjukkan tidak terdapat perbedaan sebelum dan sesudah JKN pada jumlah obat yang diterima oleh pasien, obat generik, kesesuaian dengan Daftar Obat Esensial Nasional (DOEN) dan Formularium Nasional (FORNAS).

Kata kunci: Jaminan Kesehatan Nasional (JKN); profil pengobatan; hipertensi
\end{abstract}

\section{ABSTRACT}

National Health Insurance (NHI) had been applied by Indonesia's Healthcare and Social Security Agency (BPJS) since January 2014. There also had been basic changes on its financing. Before $\mathrm{NHI}$, drug procurement was conducted by Pharmacy warehouse in regency, meanwhile in the period of NHI. By the changes on procurement system in Community Health Center, it can affect on drug availability which then affect on clinical outcomes of hypertension patients. Hypertension is one of the chronically diseases requiring comprehensive service and it faces increasing number of patients. This research aims to determine and compare profile of anti-hypertension drug availability of Hypertension ASKES patients in Pulogadung sub district community health center. It evaluated before and after NHI. This research was use longitudinal time series design and retrospective data research flow of before and after NHI. Patient criteria were inclusion ASKES hypertension patients taking routine outpatient treatments in Pulogadung sub district community health center during the period of January 2013 - December 2015; it was obtained 82 patients as the research samples. The data had been taken from medical records, Drug Use and Demand Sheet Report (LPLPO), stock cards, drug offer and demand books, hypertension patient prescription in 2013, 2014 and 2015. Results of the research determine that hypertension patient profile in treatment profile indicate no differences 
between before and after $\mathrm{NHI}$ in terms of number of received drugs by the patients, generic drugs, suitability with National Essential Drugs List (DOEN) and National Formularium (FORNAS).

Keywords: National Health Insurance (NHI); drug profile; hypertension

\section{PENDAHULUAN}

Jaminan Kesehatan Nasional (JKN) telah resmi dilaksanakan oleh BPJS (Badan Penyelenggara Jaminan Sosial). Berdasarkan PERMENKES RI No. 28 Thn. 2014, JKN merupakan perlindungan kesehatan berdasarkan prinsip asuransi sosial dan ekuitas agar peserta memperoleh manfaat pemeliharaan dan perlindungan kesehatan. Peserta diwajibkan membayar iuran atau iurannya dibayar oleh pemerintah (Kemenkes, 2014).

Pada tahun 2013, sebelum diberlakukannya JKN, jenis asuransi terbagi menjadi ASKES dan BPJS. Pada masa sebelum pelaksanaan JKN, metode pembayaran klaim rumah sakit kepada ASKES atau BPJS menggunakan metode Fee For Service (FFS). FFS adalah metode pembayaran biaya pengobatan dan obat berdasarkan pelayanan yang diberikan. Pada metode ini, tidak terdapat batasan jumlah pelayanan yang diterima oleh pemilik asuransi. Sementara itu sesudah pemberlakuan JKN metode pembayaran klaim menggunakan prinsip yang berbeda yang dikenal dengan metode INA-CBGs (Adisasmito, 2007) Pada metode ini rumah sakit tidak lagi merinci tagihan berdasarkan rincian pelayanan yang diberikan, melainkan hanya dengan menyampaikan diagnosis keluar pasien dan kode DRG. Berbeda dengan FFS yang besarnya biaya pengobatan dan perawatan tergantung pada setiap tindakan pengobatan dan jasa pelayanan yang diberikan rumah sakit sehingga biaya pengobatan lebih dapat dikontrol (Adisasmito, 2007).

Pada era JKN daftar obat-obatan yang masuk dalam paket pelayanan JKN dituangkan ke dalam Formularium Nasional (FORNAS), yaitu sebuah buku pedoman yang berisi daftar nama obat peserta aturan jumlah obat dan frekuensi yang dapat dilayani oleh fasilitas kesehatan kepada peserta JKN (Kemenkes, 2013).

Dalam menjalankan sistem JKN harus ada kerjasama antara BPJS kesehatan dengan fasilitas kesehatan sebagai pemberi layanan kesehatan fasilitas Kesehatan Tingkat Pertama (FKTP) seperti Puskesmas, praktek dokter, dokter gigi, klinik pratama atau yang setara, dan rumah sakit kelas D atau yang setara maupun Fasilitas Kesehatan Tingkat Lanjutan (FKTL) seperti klinik utama atau yang setara, rumah sakit umum, rumah sakit khusus (Kemenkes, 2013). Kerjasama yang baik antara BPJS kesehatan dengan fasilitas kesehatan semakin penting terutama setelah diberlakukannya Program Rujuk Balik. Pelayanan Program Rujuk Balik diberikan kepada peserta BPJS Kesehatan penderita penyakit kronis, khususnya penyakit diabetes melitus, hipertensi, jantung, asma, Penyakit Paru Obstruktif Kronis (PPOK), epilepsy, stroke, schizophrenia, Systemic Lupus Erythematosus (SLE) yang sudah terkontrol/stabil namun masih memerlukan pengobatan atau asuhan keperawatan dalam jangka panjang. Pelayanan obat rujuk balik dilakukan 3 kali berturut-turut selama 3 bulan di Faskes Tingkat Pertama. Setelah 3 (tiga) bulan peserta dapat dirujuk kembali oleh Fasilitas Kesehatan Tingkat Pertama ke Fasilitas Kesehatan Rujukan Tingkat Lanjutan untuk dilakukan evaluasi oleh dokter spesialis/subspesialis.

Salah satu penyakit kronis adalah hipertensi. Hipertensi merupakan kondisi yang sering ditemukan pada pelayanan kesehatan primer kesehatan. Menurut American Heart Association (AHA) penduduk Amerika yang berusia diatas 20 tahun menderita hipertensi telah mencapai angka hingga 74,5 jiwa, namun sekitar 90-95\% kasus tidak diketahui penyebabnya. Berdasarkan hasil pengukuran tekanan darah, prevalensi hipertensi pada penduduk umur 18 tahun ke atas tahun $2007 \mathrm{di}$ Indonesia adalah sebesar $31,7 \%$. Menurut provinsi, prevalensi hipertensi tertinggi di Kalimantan Selatan $(39,6 \%)$ dan terendah di Papua Barat (20,1\%). Sedangkan jika dibandingkan dengan tahun 2013 terjadi penurunan sebesar 5,9\% (dari 31,7\% menjadi 25,8\%) (Kemenkes, 2014). Gambaran di tahun 2013 dengan menggunakan unit analisis individu menunjukkan bahwa secara nasional $25,8 \%$ penduduk Indonesia menderita penyakit hipertensi. Jika saat ini penduduk Indonesia sebesar 252.124.458 jiwa maka terdapat 65.048.110 jiwa yang menderita hipertensi (Alkes, 2007). 
Tabel I. Data Demografi pasien

\begin{tabular}{lcc}
\hline Data Demografi Pasien & Jumlah & $\mathbf{\%}$ \\
\hline Usia & 3 & 3,66 \\
$35-44$ & 20 & 24,39 \\
$45-54$ & 33 & 40,24 \\
$55-64$ & 26 & 31,71 \\
$\geq 65$ & & \\
Jenis Kelamin & 32 & 39,02 \\
Laki-laki & 50 & 60,98 \\
$\quad$ Perempuan & & \\
Lama Menderita & 63 & 76,83 \\
1 - 5 Tahun & 16 & 19,51 \\
- 10 Tahun & 3 & 3,66 \\
11 - 15 Tahun & & \\
Penyakit Penyerta & 35 & 42,68 \\
Rematik & 13 & 15,85 \\
Hiperurisemia & 17 & 20,73 \\
Diabetes & 7 & 8,54 \\
Hiperkolesterolemia & 10 & 12,20 \\
Tanpa penyakit penyerta & & \\
\hline
\end{tabular}

Tujuan penelitian ini adalah untuk melihat pengaruh penerapan metode Indonesian Case Base Groups (INA-CBGs) pada program JKN terhadap profil pemenuhan obat pada pasien kronis hipertensi. Profil pemenuhan obat dilihat berdasarkan jumlah pemenuhan obat kepada pasien, golongan obat INN generik dan non generik, kesesuaian terhadap DOEN dan FORNAS, jenis obat hipertensi, serta golongan obat lain (non hipertensi).

\section{METODE}

Desain studi penelitian yang digunakan adalah desain studi longitudinal time series dengan alur penelitian data secara retrospektif sebelum JKN (tahun 2013) dan sesudah JKN (tahun 2014). Populasi dalam penelitian ini adalah semua pasien hipertensi rawat jalan. Kriteria inklusi yaitu (1) Pasien ASKES didiagnosa hipertensi rawat jalan periode Januari 2013 - Desember 2015 di Puskesmas Kecamatan Pulogadung ; (2) Pasien ASKES rawat jalan rutin melakukan 3 kali kunjungan sebelum masa JKN dan 3 kali setelah JKN rawat jalan selama periode Januari 2013 - Desember 2015 di Kecamatan Pulogadung. Kriteria eksklusi pada penelitian ini adalah pasien ASKES dengan diagnosa hipertensi rawat jalan Juli 2013 - Desember 2015 di Puskesmas Kecamatan Pulogadung yang tidak memiliki data lengkap seperti pemeriksaan darah, pasien ASKES yang meninggal saat diberlakukannya JKN.

Pengolahan dan analisa data, dilakukan dengan tahapan analisa secara asosiatif hubungan kausal (sebab akibat) untuk melihat seberapa besar pengaruh penerapan untuk metode Indonesian Case Base Groups (INA-CBGs) pada program JKN terhadap profil pemenuhan obat pada pasien kronis hipertensi dibandingkan dengan metode Free For Service (FFS). Selanjutnya data dilakukan analisa statistik menggunakan Uji Koefisien Kontingensi. Hipotesis yang dibuat adalah $\mathrm{H}_{0}$ tidak ada hubungan yang signifikan terhadap antara metode Indonesian Case Base Groups (INA-CBGs) dengan metode Free For Service (FFS) terhadap profil pemenuhan obat pada pasien kronis hipertensi.

\section{HASIL DAN PEMBAHASAN Sosiodemografi Pasien}

Jumlah pasien hipertensi rawat jalan pada tahun 2013 adalah 810 pasien Dari 810 pasien yang memenuhi syarat inklusi yaitu pasien yang melakukan kunjungan minimal 3 kali setiap tahunnya, yaitu dari Januari 2013 sampai dengan Desember 2015 sebanyak 82 pasien.

Berdasarkan tabel I mengenai data demografi pasien menunjukkan dari distribusi 
Tabel II. Profil tingkatan hipertensi berdasarkan karakteristik sosiodemografi

\begin{tabular}{|c|c|c|c|c|c|c|c|c|}
\hline & \multicolumn{2}{|c|}{ Normal } & \multicolumn{2}{|c|}{ Prehipertensi } & \multicolumn{2}{|c|}{ HT Derajat I } & \multicolumn{2}{|c|}{ HT Derajat II } \\
\hline & Jumlah & $\%$ & Jumlah & $\%$ & Jumlah & $\%$ & Jumlah & $\%$ \\
\hline \multicolumn{9}{|l|}{ Jenis kelamin } \\
\hline Laki-Laki & 3 & 3,66 & 22 & 26,83 & 17 & 20,73 & 8 & 9,76 \\
\hline Perempuan & 4 & 4,88 & 14 & 17,07 & 10 & 12,19 & 4 & 4,88 \\
\hline \multicolumn{9}{|l|}{ Umur } \\
\hline 35-44 tahun & 0 & 0 & 0 & 0 & 3 & 3,66 & 0 & 0 \\
\hline 45-54 tahun & 2 & 2,44 & 11 & 13,41 & 5 & 6,1 & 2 & 2,44 \\
\hline 55-64 tahun & 3 & 3,66 & 13 & 15,85 & 11 & 13,41 & 6 & 7,32 \\
\hline$\geq 65$ tahun & 2 & 2,44 & 12 & 14,63 & 8 & 9,76 & 4 & 4,88 \\
\hline \multicolumn{9}{|c|}{ Lama Menderita } \\
\hline 1-5 tahun & 6 & 7,31 & 28 & 34,15 & 21 & 25,61 & 8 & 9,75 \\
\hline 6-10 tahun & 1 & 1,22 & 7 & 8,54 & 6 & 7,32 & 2 & 2,44 \\
\hline 11-15 tahun & 0 & 0 & 1 & 1,22 & 0 & 0 & 2 & 2,44 \\
\hline
\end{tabular}

82 pasien mulai rentan terkena hipertensi mulai usia 45 - 74 tahun. Jumlah tertinggi terjadi antara umur 55-64 tahun sebesar 40,24\%. Menurut Penelitian Aris Sugiharto menyatakan bahwa semakin bertambahnya usia semakin besar resiko terkena hipertensi, umur 36-45 lebih besar resiko sebanyak 1,23 kali dibandingkan umur 25-35 tahun. Umur 56-65 tahun lebig beresiko 4,76 kali dibandingkan dengan umur 25-35 tahun. Umur merupakan faktor resiko yang tidak dapat dimodifikasi. Arteri kehilangan elastisitas atau kelenturan seiring bertambahnya usia, kebanyakan hipertensi akan meningkat berumur lima puluhan dan enampuluhan (Sugiharto, 2017).

Berdasarkan kelamin, hipertensi banyak terjadi pada wanita dibandingkan dengan lakilaki. Persentase pasien perempuan sejumlah 40 orang $(60,98 \%)$, sedangkan laki-laki sejumlah 25 orang $(39,02 \%)$. Hal ini serupa dengan penelitian lain yang menyatakan bahwa ratarata perempuan akan mengalami peningkatan resiko tekanan darah tinggi (hipertensi) setelah menopause yaitu diatas 45 tahun (Wahyuni \& Eksanoto, 2017). Perempuan yang belum menopause dilindungi oleh hormon estrogen yang berperan dalam meningkatkan High Density Lipoprotein (HDL). Kadar kolesterol HDL rendah dan tingginya kolesterol LDL (Low Density Lipoprotein) mempengaruhi terjadinya proses aterosklerosis (Kemenkes, Mencegah dan Mengontrol Hipertensi, 2014).

Berdasarkan lamanya pasien hipertensi menderita penyakit hipertensi terlihat bahwa pasien paling banyak menderita hipertensi selama 1-5 tahun sebesar 76,83\%. Penelitian lain mengatakan bahwa semakin lama penderita menderita hipertensi semakin tinggi resiko mengalami GGT (Gagal Ginjal Terminal) (Nurjanah, 2017). Pasien hipertensi Puskesmas Kecamatan Pulogadung adalah pasien hipertensi dengan tekanan darah yang tidak terlalu parah, karena bila ada penyakit penyerta akan di rujuk ke Fasilitas Kesehatan Tingkat Lanjutan (FKTL).

Berdasarkan penyakit penyerta didapatkan persentase hasil penyakit penyerta yang paling banyak diderita oleh pasien hipertensi adalah rematik sejumlah 42,68\%. Hipertensi dalam penyakit mikrovaskuler akan mengakibatkan iskemi jaringan yang akan meningkatkan sintesis asam urat melalui degradasi ATP menjadi adenine dan xantin.

\section{Profil tingkatan hipertensi berdasarkan karakteristik sosiodemografi}

Pada Tabel II, bila dilihat dari faktor usia hasil penelitian di Puskesmas Kecamatan Pulogadung menunjukkan bahwa hipertensi dimulai pada umur 45 tahun. Hal ini sesuai dengan penyataan bahwa tekanan darah meningkat seiring dengan bertambahnya usia sesesorang (Sugiharto, 2017). Pasien hipertensi di Puskesmas Kecamatan Pulogadung bila dilihat dari pengelompokkan usia dapat terlihat pasiennya menderita hipertensi dengan tingkatan hipertensi yaitu prehipertensi dengan tekanan darah sistol 120-139 mmHg dan tekanan darah diastole 80-89 $\mathrm{mmHg}$. Hal ini memperlihatkan bahwa pasien hipertensi di Puskesmas Kecamatan Pulogadung merupakan pasien dengan tekanan darah yang belum parah dan tidak mengalami komplikasi. Pasien dengan stage hipertensi prehipertensi paling banyak 


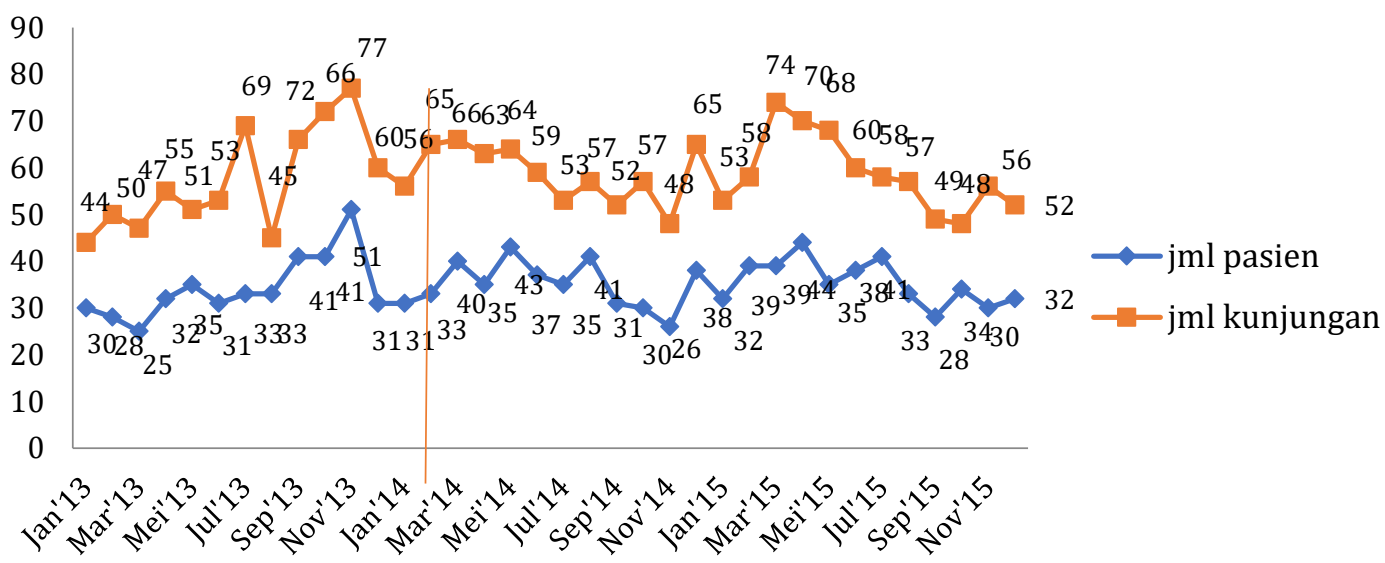

Gambar 1. Profil jumlah kunjungan dan jumlah pasien hipertensi periode Januari 2013Desember 2015

Keterangan: Jumlah kunjungan: Jumlah total kunjungan semua pasien/bulan ke PKM Pulogadung; Jumlah pasien: Jumlah pasien yang berkunjung ke PKM Pulogadung per bulan

menderita hipertensi antara 1-5 tahun. Hal ini juga sesuai dengan pernyataan bahwa lamanya penderita dengan bertambah parahnya tingkatan hipertensi. Karena Pasien hipertensi di Puskesmas Kecamatan pulogadung merupakan pasien dengan tekanan darah yang belum parah. Apabila hipertensi bertambah parah maka perlu dirujuk ke Fasilitas Kesehatan Tingkat Lanjutan (FKTL).

\section{Jumlah kunjungan}

Kunjungan Pasien dalam studi ini meliputi jumlah kunjungan pasien dan rata-rata kunjungan pasien per bulan periode Januari 2013-Desember 2015. Berdasarkan gambar 1 dapat terlihat jumlah kunjungan pasien hipertensi PKM Pulogadung periode Januari 2013-Desember 2015. Jumlah kunjungan sebelum JKN (tahun 2013) berkisar antara 44 sampai dengan 77 kunjungan. Jumlah pasien sebelum JKN (tahun 2013) berkisar antara 25 sampai dengan 51 pasien. Untuk kunjungan pasien sesudah JKN (tahun 2014 dan 2015) berkisar 48 sampai dengan 74 kunjungan. Untuk jumlah pasien setelah JKN (tahun 2014 dan 2015) berkisar antara 26 sampai 44 pasien.

Berdasarkan gambar 1 terlihat bahwa pasien hipertensi di Puskesmas Kecamatan Pulogadung tidak melakukan kunjungan setiap bulannya. Untuk pasien yang mempunyai penyakit kronis seharusnya melakukan kunjungan rutin setiap bulannya untuk mendapatkan obat hipertensi sehingga menjaga tekanan darah dan tidak akan mengakibatkan tekanan darah yang tidak terkendali atau bahkan mengakibatkan komplikasi.

Berdasarkan hasil uji statistik yang menggunakan Uji Koefisien Kontingensi tidak terdapat perbedaan yang bermakna antara jumlah rata-rata kunjungan pasien dengan nilai $\mathrm{t}$ hitung $(0,00042)<\mathrm{t}$ tabel $(0,228)$. Hal ini dikarenakan baik sebelum era JKN dan sesudah JKN pasien yang datang untuk melakukan pengobatan hipertensi tidak teratur dalam kunjungannya baik era sebelum JKN maupun sesudah JKN.

Gambar 2 memperlihatkan rata-rata kunjungan pasien hipertensi di PKM Pulogadung. Pada sebelum JKN (tahun 2013) rata-rata kunjungan berkisar 1,36 sampai 2,09. Rata-rata kunjungan sebelum JKN adalah 1,69. Sesudah JKN (tahun 2014 dan 2015) rata-rata kunjungan berkisar 1.41 sampai 1,97. Rata-rata kunjungan sesudah JKN 1,68. Bila dilihat pada jumlah pasien dan jumlah kunjungan, pasien tidak selalu datang untuk kontrol teratur dalam tiap bulannya. Hal ini mungkin terjadi karena strategi pasien supaya dapat ter-cover oleh BPJS.

\section{Pengaruh JKN terhadap profil obat ditinjau dari jumlah obat \\ Penelitian ini untuk melihat tren rata- rata jumlah obat yang diterima pasien per peresepan satu tahun sebelum JKN sampai dengan dua tahun setelah JKN.}




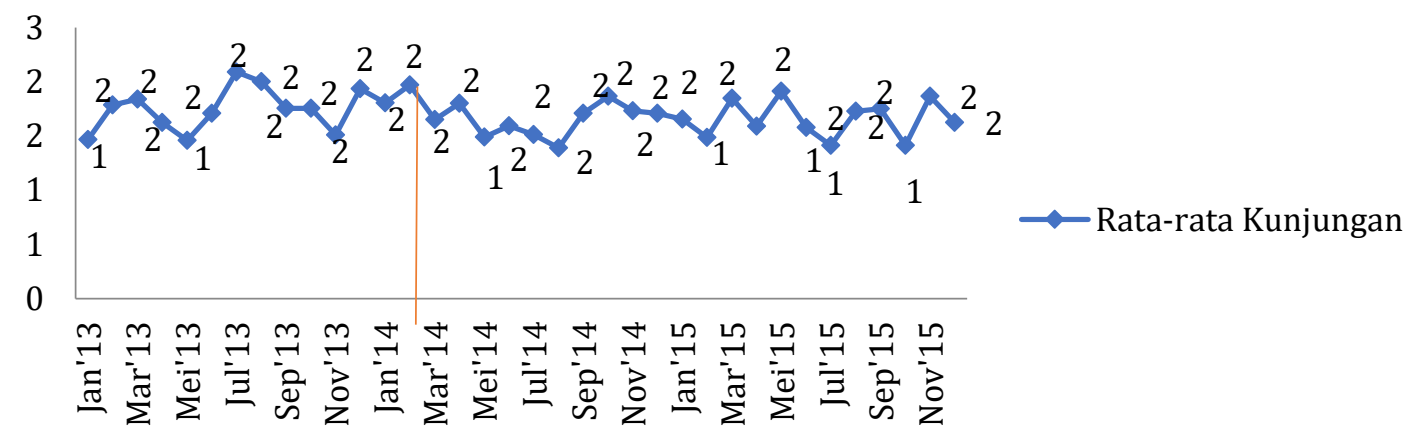

Gambar 2. Rata-rata jumlah kunjungan per bulan pasien hipertensi periode Januari 2013-Desember 2015

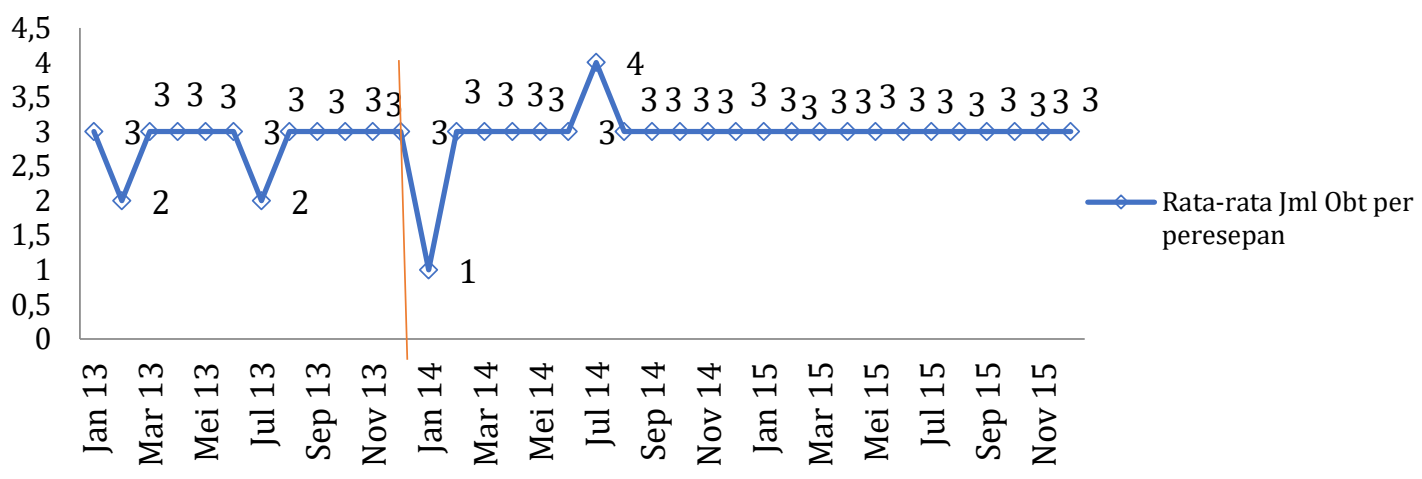

Gambar 3. Profil rata-rata jumlah obat per peresepan pasien rawat jalan hipertensi di Puskesmas Pulogadung

Gambar 3 menunjukkan tren rata-rata jumlah obat yang diterima pasien per peresepan satu tahun sebelum JKN (tahun 2013) sampai dengan dua tahun setelah JKN (tahun 2014 dan 2015). Pada gambar diatas terlihat jumlah obat per peresepan berkisar antara 1 sampai dengan 4. Rata-rata jumlah peresepan sebelum JKN (tahun 2013) 2,8. Rata-rata jumlah peresepan sesudah JKN (tahun 2014 dan 2015) berkisar 1 sampai dengan 4. Rata-rata jumlah peresepan 3.

Dari hasil penelitian dapat dilihat bahwa pada era sebelum JKN (tahun 2013) dan sesudah JKN tidak terdapat perbedaan dalam jumlah obat yang diterima oleh pasien hipertensi di Puskesmas Kecamatan Pulogadung. Terjadi peningkatan pada era JKN pada Bulan Juli 2014 sebanyak 4 jenis macam obat. Pada awal diberlakukannya JKN yatitu pada Bulan Januari 2014 rata-rata jumlah obat yang diterima oleh pasien 1 obat, hal ini dikarenakan pada awal tahun 2014 sedang terjadi peralihan sistim pengadaan obat sehingga ini menyebabkan obat di Puskesmas persediaannya tidak terlalu banyak.

Berdasarkan hasil uji statistik yang menggunakan Uji Koefisien Kontingensi tidak terdapat perbedaan yang bermakna antara jumlah pemenuhan obat kepada pasien dengan nilai t hitung $(0,005)<\mathrm{t}$ tabel $(0,228)$. Hal ini dikarenakan obat-obat yang diterima oleh pasien hipertensi sebelum era JKN dan sesudah JKN sama untuk jenis obat hipertensi.

\section{Pengaruh JKN terhadap profil obat ditinjau dari obat INN generik dan non-generik}

Pada era JKN, obat-obat yang diresepkan berpedoman pada Formularium Nasional. Pada formularium tersebut, secara umum obat-obat yang dicover oleh JKN adalah obat INN generik.

Gambar 4 merupakan rata-rata jumlah penggunaan obat generik dan non generik pada pasien hipertensi di Puskesmas Kecamatan Pulogadung. Sebelum JKN (tahun 2013) berkisar 1 sampai 3. Rata-rata sebelum JKN 


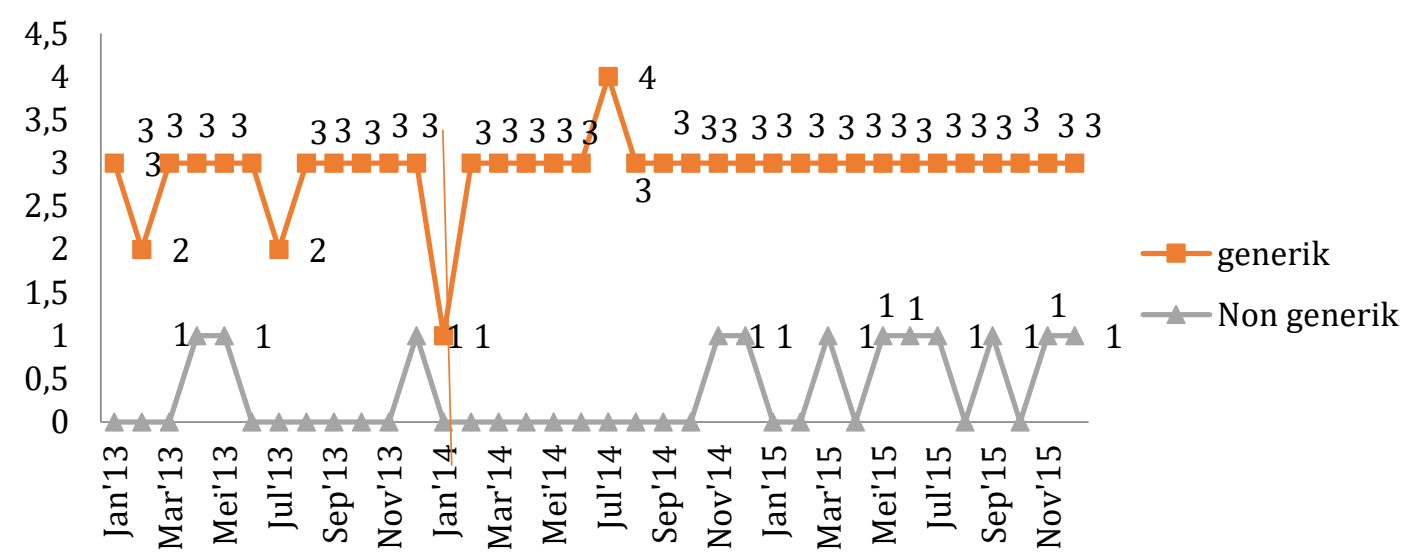

Gambar 4. Rata-rata jumlah penggunaan obat INN generik dan non INN generik pada pasien hipertensi di Puskesmas Kecamatan Pulogadung tahun 2013-2015

(tahun 2013) 3. Sesudah JKN (tahun 2014 dan 2015) rata-rata penggunaan obat generik berkisar 1 sampai dengan 4. Rata-rata jumlah penggunaan setelah JKN (tahun 2014 dan 2015) 3,3 . Hal ini sudah sesuai dengan kebijakan yang ada, bahwa dokter yang bertugas di fasilitas pelayanan kesehatan pemerintah wajib menulis resep obat generik bagi semua pasien sesuai dengan indikasi medis (Kemenkes, PERMENKES RI No. HK.02.02 Thn. 2010 Tentang Kewajiban Menggunakan Obat Generik di Fasilitas Pelayanan Kesehatan Pemerintah, 2010).

Namun, terdapat obat-obat tertentu seperti obat FG troches, Neurovit E yang diresepkan. Pada tahun 2013 dapat terlihat masih adanya penggunaan obat non generik, hal ini terjadi karena pada tahun 2013 pasien yang datang adalah pasien ASKES, dimana obat yang digunakan adalah obat yang terdapat di DOEN. Pada daftar DOEN memang tidak terdapat nama obat dagang, namun di Puskesmas Kecamatan Pulogadung terdapat kebijakan apabila terdapat obat yang tidak terdapat pada DOEN maka akan dilakukan pengadaan yang dananya bersumber dari retribusi yang didapatkan oleh Puskesmas. Sedangkan pada era sesudah JKN masih terlihat pemakaian obat non generik. Sama halnya dengan sebelum JKN obat generik diberikan karena dokter menginginkan pasien mendapatkan obat non generik tersebut.

Berdasarkan hasil uji statistik yang menggunakan Uji Koefisien Kontingensi tidak terdapat perbedaan yang bermakna antara jumlah penggunaan obat INN generik dan non generik dengan nilai $t$ hitung $(0,006)<t$ tabel
(0,228). Hal ini dikarenakan obat yang digunakan di Puskesmas kecamatan Pulogadung adalah obat generik dan hal ini sesuai dengan Permenkes bahwa dokter yang bertugas di fasilitas pelayanan kesehatan milik pemerintah wajib menuliskan resep obat generic (Kemenkes, PERMENKES RI No. HK.02.02 Thn. 2010 Tentang Kewajiban Menggunakan Obat Generik di Fasilitas Pelayanan Kesehatan Pemerintah, 2010)

\section{Pengaruh JKN terhadap profil obat ditinjau dari kesesuaian terhadap DOEN dan FORNAS} Daftar Obat Esensial Nasional adalah daftar obat terpilih yang paling dibutuhkan untuk pelayanan kesehatan, mencakup upaya diagnosis, profilaksis, terapi dan rehabilitasi, yang diupayakan tersedia di fasilitas kesehatan sesuai dengan fungsi dan tingkatnya. FORNAS merupakan formularium nasional yang dijadikan sebagai rujukan obat-obat yang diresepkan untuk pasien JKN.

Pada gambar 5 terlihat persentase kesesuaian peresepan obat dengan DOEN dan FORNAS. Analisa kesesuaian peresepan obat sebelum JKN dilakukan periode 2013 dengan pedoman DOEN. Sedangkan kesesuaian peresepan dengan FORNAS dilakukan pada periode waktu 2014 dan 2015. Dari gambar 5 di atas dapat terlihat bahwa pada era sebelum JKN (tahun 2013) ketidaksesuaian obat yang diresepkan dengan DOEN adalah berkisar 96\% sampai dengan 97\%. Hal ini dikarenakan ada obat-obat yang memang harus diberikan oleh dokter kepada pasien karena pasien 


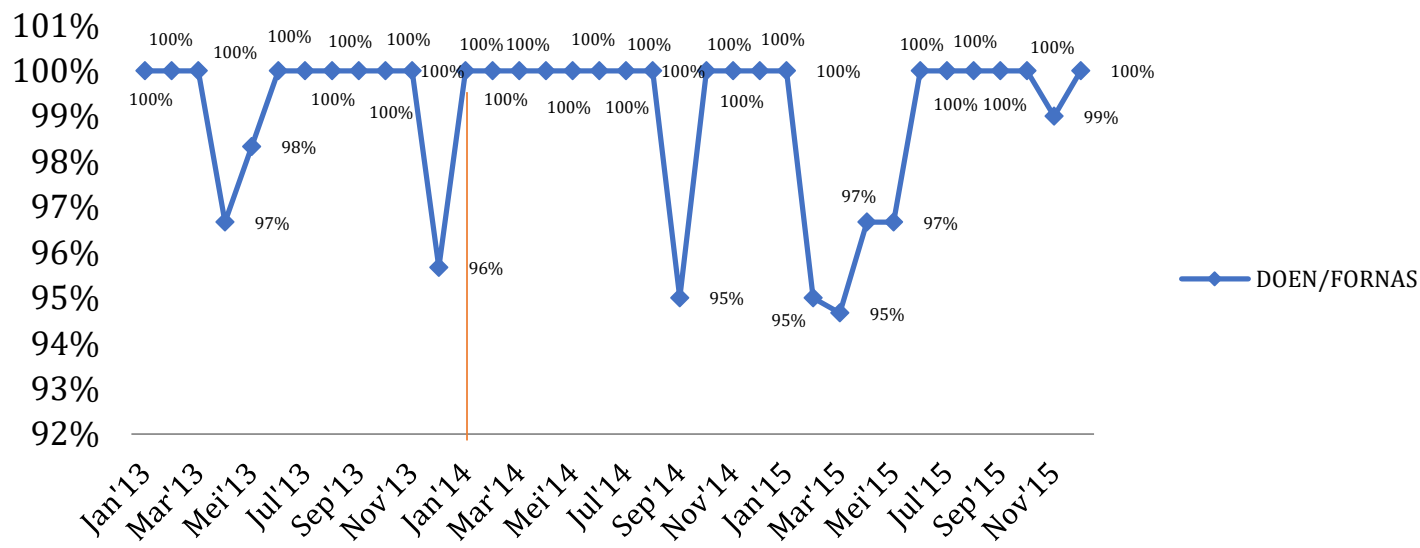

Gambar 5. Persentase kesesuaian obat yang diresepkan dengan DOEN dan FORNAS pada pasien hipertensi periode Januari 2013-Desember 2015

Tabel III. Jenis-jenis obat hipertensi

\begin{tabular}{lcccccc}
\hline \multirow{2}{*}{ Nama Obat } & \multicolumn{3}{c}{ Sebelum JKN } & \multicolumn{3}{c}{ Sesudah JKN } \\
\cline { 2 - 7 } & \multicolumn{2}{c}{$\mathbf{2 0 1 3}$} & $\mathbf{2 0 1 4}$ & \multicolumn{2}{c}{$\mathbf{2 0 1 5}$} \\
\cline { 2 - 7 } & N(Resep) & $\mathbf{\%}$ & N(Resep) & \% & N(Resep) & \% \\
\hline Amlodipin 5 mg & 65 & 2,39 & 268 & 8,18 & 892 & 27,45 \\
Amlodipin 10 mg & 0 & 0,00 & 0 & 0,00 & 192 & 5,91 \\
HCT 25 mg & 145 & 5,32 & 292 & 8,92 & 252 & 7,75 \\
Kaptopril 12,5 mg & 1179 & 43,27 & 1147 & 35,02 & 1167 & 35,91 \\
Kaptopril 25 mg & 729 & 26,75 & 1046 & 31,94 & 544 & 16,74 \\
Nifedipin 10 mg & 607 & 22,28 & 522 & 15,94 & 203 & 6,25 \\
\hline
\end{tabular}

membutuhkan. Obat tersebut adalah Anusol sup, sangobion, ambroxol dan GG.

Dari gambar di atas terlihat obat-obat yang diresepkan $100 \%$ telah sesuai dengan FORNAS namun pada Bulan September 2014; Februari sampai Mei 2015 terdapat penurunan kesesuaian obat dengan FORNAS. Hal ini mungkin dikarenakan obat-obat yang tidak sesuai dengan FORNAS adalah obat-obat yang digunakan untuk mengurangi efek samping pada penggunaan obat hipertensi.

Berdasarkan hasil uji statistik yang menggunakan Uji Koefisien Kontingensi tidak terdapat perbedaan yang bermakna antara persentase kesesuaian dengan DOEN dan FORNAS dengan nilai $t$ hitung $(0,017)<t$ tabel $(0,228)$.

\section{Pengaruh JKN terhadap profil obat ditinjau dari jenis-jenis obat hipertensi}

Jenis obat hipertensi adalah obat hipertensi yang digunakan di Puskesmas Kecamatan Pulogadung. Untuk ketersediaan obat di Puskesmas Kecamatan Pulogadung obat hipertensi yang tersedia adalah amlodipin $5 \mathrm{mg}$, amlodipin mg, HCT, kaptopril 12,5 mg, kaptopril $25 \mathrm{mg}$ dan nifedipin.

Pada tabel III terlihat jenis obat hipertensi yang terdapat di Puskesmas Kecamatan Pulogadung, dan dibandingkan sebelum era JKN (tahun 2013) dan sesudah JKN (tahun 2014 dan 2015). Dari data diatas terlihat dari tahun ke tahun terdapat konsistensi bahwa jumlah obat hipertensi yang paling banyak digunakan adalah Kaptopril tablet. Hal ini dikarenakan pasien hipertensi di Puskesmas Kecamatan Pulogadung dalah pasien adalah pasien dengan tingkatan hipertensi adalah prehipertensi dengan TD 120/80-139/90. Kaptopril efektif digunakan untuk hipertensi ringan. Sehingga untuk pasien hipertensi di Puskesmas Kecamatan Pulogadung banyak diberikan Kaptopril. pada tabel di atas amlodipin $5 \mathrm{mg}$ sesudah JKN mengalami kenaikan jumlahnya. 
Pengaruh JKN terhadap profil obat ditinjau dari golongan obat lain (non hipertensi)

Golongan obat non hipertensi merupakan golongan obat-obat yang diterima oleh pasien hipertensi rawat jalan Puskesmas Kecamatan Pulogadung selain obat hipertensi yang digunakan karena adanya keluhan lain selain hipertensi.

Penggunaan obat selain obat hipertensi diidentifikasi penggunaannya di Puskesmas Kecamatan Pulogadung 10 terbanyak adalah golongan vitamin, NSAID, obat diabetes, mineral, antasida, obat batuk, antibiotik, obat diare, antihistamin dan kolesterol. Obat non hipertensi didapatkan oleh pasien hipertennsi digunakan untuk mengurangi gejala lain yang dialami oleh pasien hipertensi. Pasien hipertensi di Puskesmas Kecamatan Pulogadung rata-rata ber usia diatas 50 tahun. Obat non hipertensi yang paling banyak digunakan adalah golongan vitamin sebelum JKN 39,37 \% sedangkan sesudah JKN 40,99\%. Dari golongan tersebut, yang paling banyak digunakan adalah vitamin B komplek. Hal ini sesuai dengan keadaan pasien dimana pasien sudah termasuk dalam golongan lansia sehingga panambahan vitamin sangat diperlukan, karena vitamin B komplek adalah bahan baku pembuatan enzim. Enzim merupakan suatu komponen yang menjamin metabolism dalam tubuh sehingga stamina pasien tetap terjaga. Golongan kedua terbanyak adalah NSAID, jumlah sesudah JKN 51,97\%, hal ini sesuai dengan data pada tabel 1 dimana penyakit penyerta yang paling banyak terdapat di Puskesmas Kecamatan Pulogadung adalah rematik sehingga perlu ditambahkan golongan obat NSAID. Selain itu golongan NSAID juga digunakan untuk mengurangi gejala hipertensi seperti pusing. Sedangkan obat batuk ditambahkan untuk mengurangi efek samping dari pemakaian kaptopril yaitu batuk (Amir, Ari, \& Arini, 2007)

\section{KESIMPULAN}

Penerapan metode Indonesian Case Base Groups (INA-CBGs) pada program JKN tidak berpengaruh secara signifikan terhadap profil pemenuhan obat pada pasien kronis hipertensi yang diresepkan berdasarkan ketersediaan obat di Pukesmas Kecamatan Pulogadung.

\section{UCAPAN TERIMA KASIH}

Puskesmas Kecamatan Pulogadung atas bantuannya dalam pengambilan data penelitian ini.

\section{DAFTAR PUSTAKA}

Adisasmito, W. (2007). Sistem Kesehatan. Jakarta: Jasa Grafindo Persada.

Alkes, D. B. (2007). Pedoman Pengelolaan Obat Publik dan Perbekalan Kesehatan di Daerah Kepulauan. Jakarta: Kementerian Kesehatan RI.

Amir, S., Ari, E., \& Arini, S. (2007). Farmakologi dan Terapi Edisi V. Jakarta: Badan Penerbit Fakultas Kedokteran Universitas Indonesia.

Kemenkes, R. (2010). PERMENKES RI No. HK.02.02 Thn. 2010 Tentang Kewajiban Menggunakan Obat Generik di Fasilitas Pelayanan Kesehatan Pemerintah. Jakarta: Kementerian Kesehatan RI.

Kemenkes, R. (2013). Laporan Akuntabilitas Kerja DIRJEN Bina Kefarmasian dan Alkes Tahun 2013. Jakarta: Kementerian Kesehatan RI.

Kemenkes, R. (2014). Mencegah dan Mengontrol Hipertensi. Jakarta: Kementerian Kesehatan RI.

Kemenkes, R. (2014). PERMENKES RI No. 28 Thn. 2014 Tentang Pedoman Pelaksanaan Program Jaminan Kesehatan Nasional Indonesia. Jakarta: Kementerian Kesehatan.

Nurjanah, A. (2017). Hubungan Antara Lama Hipertensi dengan Angka Kejadian Gagal Ginjal Terminal (GGT) di RSUD Dr. Soewardi Surakarta. Surakarta.

Sugiharto, B. (2017). Faktor-Faktor Resiko Hipertensi Grade II Pada Masyarakat (Studi Kasus di Kabupaten Karang Anyar). Semarang: Universitas Diponegoro.

Wahyuni, \& Eksanoto. (2017). Hubungan Tingkat Pendidikan dan Jenis Kelamin dengan Tingkat Kejadian Hipertensi di Kelurahan Jagalan di Wilayah Kerja Puskesmas Pucang Sawit Surakarta. Jurnal Ilmu Keperawatan Indonesia, 1-2. 